\title{
A STUDY OF EXPRESSIVE WRITING SKILLS AND USE OF WRITING STRATEGIES IN ENGLISH AMONG HIGH SCHOOL STUDENTS
}

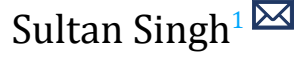 \\ ${ }^{1}$ Research Scholar, Department of Education, Punjab University, Chandigarh, India. Tel.: 9991109294
}

Received 2 June 2021

Accepted 18 June 2021

Published 30 June 2021

Corresponding Author

Sultan Singh, sultansinghkalia@g

mail.com9991109294

DOI 10.29121/

granthaalayah.v9.i6.2021.4042

Funding: This research received no specific grant from any funding agency in the public, commercial, or not-for-profit sectors.

Copyright: (C) 2021 The Author(s). This is an open access article distributed under the terms of the Creative Commons Attribution License, which permits unrestricted use, distribution, and reproduction in any medium, provided the original author and source are credited.

\section{ABSTRACT}

The intricate nature of written expression presents a difficulty for many students. Learning english as a third language is a difficult assignment. Expressive composing abilities in english can't be procured in proper learning measures. Yet, it needs remarkable endeavors made by the student. There are some broad procedures for development recorded as hard copy abilities. Do these systems are dealt with by the student for composing tasks? To discover the response to this inquiry the current examination was performed. This paper is a review report which was directed on secondary school understudies to examine the degree of expressive abilities and utilization of composing methodologies among them. The outcomes showed that understudies are very much aware of general methodologies and utilize the systems seriously during and after the assignment when contrasted with before composing tasks.

Keywords: Written Expression, Composing Task, Development, Etc

\section{INTRODUCTION}

Language is a medium that interfaces individuals and helps incomprehension of the strange of the external world. English language learning is extremely fundamental for globalization as it is a worldwide language. In our country, English is the third language after local dialects and Hindi. Here kids figure out how to communicate in their mother language. The change from the first language to Hindi and afterward English starts from pre-school. Being a third language English learning is found troublesome at certain phases of instructing learning cycle and it requires some uncommon endeavors and systems for getting authority in the English language. Composing abilities in the English language are quite possibly the most fascinating region to be assessed. Composing abilities and procedures assume an imperative part of English language learning. 


\section{SIGNIFICANCE OF STUDY}

This study was conducted to know the level of English writing skills This study was conducted on high school students from Govt. schools in Panchkula. This study also revealed some writing strategies used by students for mastering the language.

\section{Objectives}

- To assess the level of English language of high school students.

- To assess the level of writing skills of high school students.

- To know the adopted strategies for self-learning among high school students.

\section{METHODOLOGY}

A descriptive survey method was adopted for the study. The data was collected from students using a self-made questionnaire. The students were the primary source of data. The sample size was 100 participants from Panchkula.

\section{ANALYSIS}

\section{Self-Assessment of English Writing Skills}

Self-Assessment is one of the very essential components in the teaching-learning process. It motivates the learner to work hard towards perfection. Students were asked to relate various expressive writing skill-based statements to themselves. This factor is reflected in Table No-1

\begin{tabular}{lll}
\hline \multicolumn{2}{l}{ Table 1 1: Self-Assessment of English Writing Skills } \\
\hline Classification & Students & Percentage \\
1=never or rarely true of me & 20 & $20 \%$ \\
\hline 2=usually not true of me & 10 & $10 \%$ \\
3=somewhat true of me & 10 & $10 \%$ \\
4=usually true of me & 15 & $15 \%$ \\
5=always or almost always true of me & 45 & $45 \%$ \\
Total & 100 & $100 \%$ \\
\hline
\end{tabular}

The analysis of responses by students demonstrated that $45 \%$ of participants were able to relate themselves with good writing skills. The other percentage lied between $10 \%$ to $20 \%$.

\section{USE OF LEARNING STRATEGIES}

\section{a). General Strategies}

General English learning strategies like the use of an English dictionary, grammar book, reading native English writings and the use of English vocabulary in different ways are key components in language learning. 


\section{b). Before Writing}

Brainstorming, Discussion with teachers and peers, the establishment of connections between new and old learning, planning, rough drafting are some basic learning strategies which one should adopt as a habit to develop expressive writing skills.

\section{c). During Writing}

Environmental factors, Background Knowledge, Translation of native English and correct use of grammar and vocabulary are the key factors to be considered essential during the writing task

\section{d). After Writing}

Self-Appraisal, feedback recording, Analysis of feedback to improve learning, Pronunciation, Vocabulary and errors detection are major learning strategies after completing a writing task.

The trend of use of these learning strategies is reflected in Table-2

Table 2 Use of Learning Strategies

\begin{tabular}{lllll}
\hline Classification & $\begin{array}{l}\text { General } \\
\text { Strategies }\end{array}$ & Before Writing & During Writing & After Writing \\
\hline 1=never & $10 \%$ & $30 \%$ & $15 \%$ & $5 \%$ \\
\hline $2=$ rarely & $16 \%$ & $25 \%$ & $15 \%$ & $9 \%$ \\
3=sometimes & $12 \%$ & $18 \%$ & $03 \%$ & $10 \%$ \\
$4=$ often & $25 \%$ & $14 \%$ & $24 \%$ & $25 \%$ \\
\hline =most often & $37 \%$ & $23 \%$ & $43 \%$ & $51 \%$ \\
Total & $100 \%$ & $100 \%$ & $100 \%$ & $100 \%$ \\
\hline
\end{tabular}

The analysis of responses by students demonstrated that students most often used the general strategies with a percentage of $37 \%$. The percentage of students who use strategies rarely or never use them is $16 \%$ and $10 \%$ respectively. The data reflected that students use learning strategies during and after completing a writing task.

\section{FINDINGS}

The findings of the survey are listed below

- Students had good writing skills in Expressive English Writing Skills.

- Students found aware of their General Writing Skills.

- More students gave less importance to the writing skills before writing a task as compared to during and after writing a task.

\section{CONCLUSION}

The findings of the study reflected that students processed good expressive skills in English. General learning Strategies are essential for the development of writing 
tasks. The survey showed that students in high school are well aware of the strategies and they are using them during and after the task.

\section{REFERENCES}

Durga, V. S. S., \& Rao, C. S. (2018). Developing students' writing skills in English: A process approach. Journal for Research Scholars and Professionals of English Language Teaching, 6(2), 1-5.

Iftanti, E. (2016).

Kartawijaya, S. (2018). Improving Students' Writing Skill in Writing Paragraph through an Outline Technique. Curricula, 3(3). Retrieved from https://dx.doi.org/10.22216/jcc .2018.v3i3.3429 10.22216/jcc.2018.v3i3.3429

Nasir, L., Naqvi, S. M., \& Bhamani, S. (2013). Enhancing Students' Creative Writing Skills: An Action Research Project. Acta Didactica Napocensia, 6(2), 27-32.

Utami, S. (2018). Grammatical Problems in Introduction Section of Thesis Written by English Literature Students. Journal Kata: Penelitian tentang Ilmu Bahasa dan Sastra, 2(1), 107117. 